\title{
Librarians who Request for Reprints Including those in Oncology
}

\author{
Wilson Ib Onuigbo* \\ Medical Foundation and Clinic, 8Nsukka Lane, Nigeria \\ Received: 眥July 09, 2018; Published: 眥July 16, 2018 \\ *Corresponding author: Wilson Ib Onuigbo, Medical Foundation and Clinic, 8 Nsukka Lane, Enugu, Nigeria
}

\section{Abstract}

A 13-year retrospective study of reprint requestors was undertaken with special reference to those from research libraries. It was found that 2.8 percent of the total 2,053 requests were from such librarians. They preponderated in USA, East Germany, Australia, France and Britain. The reason for their requests included Reprint Library acquisitions and exhibition purposes. The librarians tended to ask for reprints from foreign rather than local Journals. All indications are that the reprint has played an important role in scientific communication. In particular, the librarians, who work in research libraries, deserve special scrutiny.

\section{Introduction}

In the 1970s and 1980s, the role of the reprint request (RR) as a means of communication came under vigorous attack. A strongly canvassed view was that researchers should, instead of requesting for reprints, obtain photocopies from libraries. For example, British advocates [1] who asserted that reprint requests are largely outdated and a waste of both time and money, wrote thus: "Doctors in our area rarely requested reprints themselves from authors, and almost all relied on arranging for photocopies of interesting article locally". "Efficient library facilities," they continued, "are a feature of medical centres in most countries". Countries probably differ in respect of library facilities. For instance, the total demand on the British Library Lending Division increased from 41,000 to 2,104,000 between 1961 and 1974 [2]. During that period, the proportion of requests from British libraries themselves rose from 7 percent to over 40 percent, i.e., a six-fold increase. Increase in the development of libraries in India may be instanced. According to Garfield [3] Ranganathan was the father of Indian Library Service. Among his achievements was the establishment of public library system in addition to the better-known systems in the universities and other centres of research. Research Libraries, including Hospital Libraries [4] constitute strong branches of the system. They deserve to be the subject of research themselves. Can this be done from Nigeria?

\section{Method}

Since after the end of the Nigerian Civil War in 1970, I have maintained records on the researchers from all over the world who requested for reprints of my publications in the fields of cancer pathology, medical history, geographical pathology and information science. In this study, emphasis will be laid on data accruing from Research Libraries.

\section{Results}

During the $1970-82$ publication period, my 69 total papers elicited 2,053 requests. Only $29(1.4 \%)$ of these papers were the subject of requests from research libraries. Twenty-two such libraries made 58 requests, i.e., $2.8 \%$ of all requests. At the extremes, 15 papers were requested only once, while 2 papers each attracted five requests. Requests were located in but 10 countries. The United States led with 17 requests which emanated from as few as 9 of the 55 states, namely, Massachusetts, 5; New York, 3; Wisconsin,2; Missouri, 2; and Maryland, New Jersey, Florida, Minnesota, and Louisiana, 1 each. East Germany followed with 13 requests. Other sources were Australia, 9; France, 8; Britain, 5; West Germany, 2; and one each from Canada, Czechoslovakia, Bulgaria, and Hungary. Apart from these countries themselves, what other patterns were traceable? Traceable was a tendency for particular research 
libraries to dominate the picture in the individual country. Indeed, all library requests from Australia came from the Cancer Institute in Melbourne. Similarly, six of the eight originating from France were from Villejuif's Gustave-Roussy Institute, while 11 of 13 from East Germany came from the Cancer Institute of the Academy based in Berlin-Buch. What other trends are in evidence? Evidence of considerable interest came from Green [5] who made the point that the reprint allows the individual to maintain a "Sublibrary" of relevant information. In fact, such a sublibrary may feature in a research library. Thus, in his quest for a reprint of my publication that appeared in the American Medical Association's Archives of Surgery, [6] the librarian of a specialized hospital in London, England, was explicit: "it will be filed in the Reprint Library and will be readily available for members of Staff and other postgraduate research workers." Indeed, the very location of reprints to a special section of such a library is indicative of their status in Informatics.

Informatics is an important subject. Accordingly, the pulling power of the RR ought to be sought in it. By way of illustration, my work on the black cancer called melanoma, published in the British Journal of Plastic Surgery, [7] drew the following dual requests: "I would be most grateful if you could let us have 2 copies of this most interesting article for our reference libraries at the Westminster and St George's Hospitals in London." Clearly, a letter, coming all the way from UK down to a Third World researcher, and requesting for a reprint of work appearing in a reputable British journal, testifies eloquently to the relative poverty of photocopies as compared with reprints. Reprints do occupy a pride of place in the field of information - at least for exhibition purposes. Consider my paper [8] on the diagnosis of lung cancer in the nineteenth century. It led to RR from the librarian of one of the Institutes of London University itself: "One day I hope to mount an exhibition on this subject in the Library here, and I am sure that your paper, together with your earlier paper in Medical History, will prove of the greatest use to me." As for other requestors, what are other trends? Trends include a surprising observation, namely, it is scarcely the obscurity of a journal that prompts a requestor to opt for a reprint. For example, 67 of the 69 papers being analyzed here were published in scientific journals covered by Current Contents. Ahead was the journal, Oncology, which drew 11 requests for its five papers. Cancer Research, Archives of Pathology and British Journal of Disease of the Chest each published two papers that yielded respectively 5 , 3 and 2 requests. Other prominent Journals whose reprints were requested included American Journal of Surgery, New York State Journal of Medicine, British Medical Journal and Scottish Medical Journal. Journal after journal found favor with research librarians. Thus, as regards American journals, there were 22 requests from foreign librarians and 9 from home ones. With regard to British Journals, the respective figures were 15 and 3 . Hence, in general, requests from abroad outnumbered those from local libraries by roughly 4 to 1 . This disparate trend is highly suggestive of the considerable importance of foreign reprints to research librarians. Librarians from a variety of institutions are involved. Actually, their variety should be spotlighted. For example, my brief communication [9] in Information Science led to a request from the librarian of the Hungarian Academy of Science. Other papers gained the same attention from diverse centres in different countries such as Biorex Laboratorues Ltd., London, England; Best Foods Research Centers, New Jerssey, USA; Institute de Cancerrologie et D'Immunogenetique, Villejuif, France; Vish Voennomedicinsk Institute, Sofia, Bulgaria; Radiologicka Klinika, Karlovy University, Prague, Czechoslovakia; and Forschungsintitut fur Tuberkulose, Berlin-Buch, East Germany.

\section{Discussion}

The above patterns indicate the importance of RR as a means of communication. As I see it personally, such requests constitute a tracer tool in scientific thoughts [10]. For instance, I used it to discover that Current Contents is the major bibliographic source [9]. My other publications traced brain drain, [11] utilization of Request-A-Print, [12] analyzing medicine, [13] sociology of surgery, [14] and the information discordances on who an "elderly" patient is [15]. Little wonder that John Swales, [16] Editor of English for Special Purposes, declared about me in 1986 thus: "the only active researcher that I have traced in the RR area." In sum, the present study, which has dealt specifically on my own writings, traced the parameters of research librarians on an international scale. Scale of the importance of RR is waning, however. Thus, I now scarcely receive requests. My Post Office Box is being starved! In fact, the Internet has made increasing inroads into that warmly personable practice which had been the personal requesting for the reprint [17]. Surprisingly, it slenderly survives in one interesting parameter. For instance, notable internet publications in my current fields still bear the terse "Address correspondence and reprint requests" (Canada) [18]; "offprint requests" (China) [19]; "Reprint requests" [20]; (Australia) [21]; "Reprint request" (Japan) [22]; and "Address for reprints" (USA).

\section{Conclusion}

My only regret is that, more often than not, Abstracts are alone provided following Internet searches. Therefore, would that Third World Scientists could receive full length papers free. Thus, as Garfield espoused when he delivered the 1982 Annual Magnus Pyke Lecture at the US Embassy in London, there is need to look keenly into Science vis-a-vis Public Policy. As he canvassed, to encourage productivity among Third World Scientists will, in all probability, yield research returns. Returns certainly came my way because of gratefully receiving free copies of the Annals of Saudi Medicine. Consequently, I was able to study its single case reports with reference to the accompanying discharge post-operative letters. I also did likewise in respect of my heaped RRs as well as the lesser Internet bounties. Perspicaciously, the word, "uneventful" cropped up again and again in the Annals of Saudi Medicine. And so was it as regards my catchment of RRs in addition to the world-wide Internet research materials. Therefore, note the staggering list of the involved countries: Australia, China, Denmark, Finland, India, 
Israel, Jordan, Korea, Kuwait, Nepal, Norway, Pakistan, Saudi Arabia, Qatar, Spain, Sultanate of Oman, Sweden, Taiwan, Turkey, UK, and USA. In this context, the Korean example merits citation complete with my italics. As it happened, the patient was aged 90 years, and her diseased ovary measured fully $21 \times 17 \times 6 \mathrm{~cm}$. Yet, her report was the germane generation thus: "Our patient like those in previous reports recovered uneventfully after surgery." Little wonder that, with this pouring rain of evidence, I had to conclude positively that English is incontrovertibly the lingua franca. Perspicaciously, the nicely named World Journal of Developing Country Education and Research had actually invited me to contribute an article. In sum, what happened? Lo and behold! It did print my above hypothesis as regards the lingua franca status of English. Moreover, this appeared as its very first article!

\section{References}

1. Macfarlane JT, Cullen MH, Banks DC (1981) Why request reprints? British Medical Journal 283: 581

2. Line MB, Wood DN (1975) The effect of a large-scale photocopying service on journal sales. Journal of Documentation 31: 234-45.

3. Garfield E (1984) A tribute to Sc R Ranganathan, the father of Indian Library Science. Current Contents 12: 3-7.

4. Morton DJ (1977) Analysis of interlibrary request by hospital libraries for photocopied journal articles. Bulletin of the Medical Library Association 65(4): 425-432.

5. Green Keith (1979) An evaluation of citation-return on reprints, College and Research Libraries 40: 11-16.

6. Onuigbo WIB (1975) Alimentary tract carcinoma in Nigerian Igbos. Archives of Surgery 110: 349.

7. Onuigbo WIB (1975) Malignant melanoma in the Igbos of Nigeria. British Journal of Plastic Surgery 28(2): 114-117.
8. Onuigbo WIB (1971) The diagnosis of lung cancer in the 19th century. British Journal of Disease of the Chest 65(2): 119-123.

9. Onuigbo WIB (1982) Printer's devil and reprint requests. Journal of the American Society for Information Science 33: 58-59.

10. Onuigbo WIB (1985) Reprint requests-a tool for documentation. International Forum on Information and Documentation 10: 7-9.

11. Onuigbo WIB (1983) Tracing of brain drain with reprint requests. Social Biology 30: 423-425.

12. Onuigbo WIB (1984) Utilization of request-a-print. Social Studies of Science 14(1): 94-96.

13. Onuigbo WIB (1985) Analyzing medicine by means of reprint requests. Methods of Information in Medicine 24: 37-39.

14. Onuigbo WIB (1991) Sociological study of surgical sciences with requested reprints. Nigerian Journal of Surgical Sciences 1: 40-48.

15. Onuigbo WIB (2010) Information discordance in reprints on cancers in the elderly. European Science Editing 36: 72-73.

16. Swinscon TDV (1981) Why request reprints? British Medical Journal 283: 988.

17.Zahn M, Zhao H, Han ZC (2004) Signaling mechanisms of anoikis. Histology and Histopathology 19(3): 973-983.

18. The WT, Vollennoven B, Harris PI (2006) Umbilical encounter when inserting the Veres needle. Fertility Sterility 86: 1764(e1-e2).

19. Taira V, Aogi K, Ohsumi S, Takashimo S, Kawamuro S, et al. (2007) Epidermoid inclusion cyst of the breast. Breast Cancer 14: 434-437.

20. Middleton LP, Amin M, Gwyn K, Theriault R, Sahin A (2003) Breast carcinoma in pregnant women: Assessment of clinicopathologic and immunohistochemical features. Cancer 98: 1055-1060.

21. Garfield E (1983) Mapping science in the Third World. Science and Public Policy 10: 112-127.

22. Onuigbo WIB (2014) The word uneventful exemplifies the lingua franca status of English. World Journal of Developing Country Education and Research 1(1): 1-5.
(C) Commons Attribution 4.0 License

To Submit Your Article Click Here: Submit Article

DOI: $10.32474 /$ OAJOM.2018.02.000136

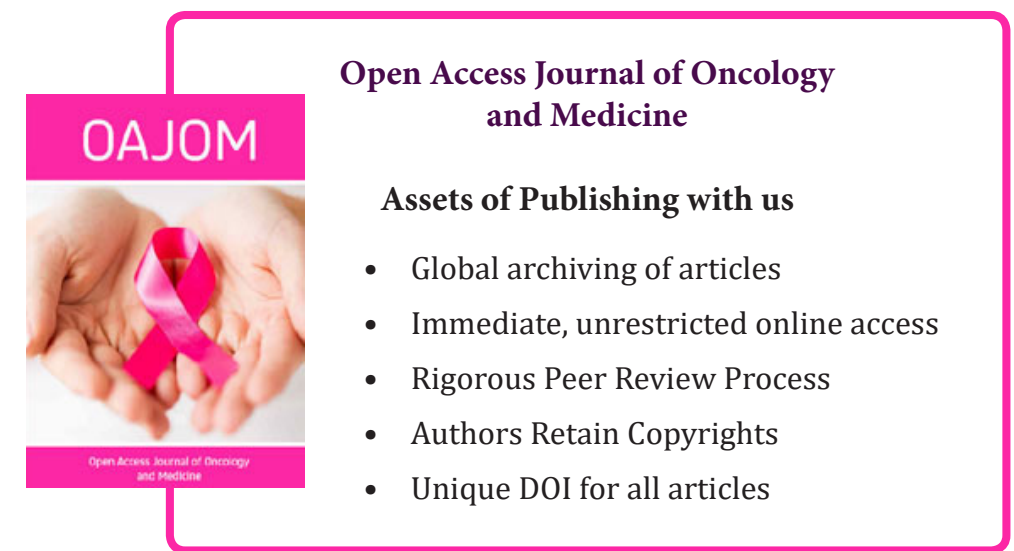

